\title{
Veterinary use of bacteriophage therapy in intensively-reared livestock
}

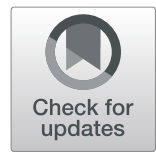

\author{
Adriano Gigante and Robert J Atterbury ${ }^{*}$ (D)
}

\begin{abstract}
Zoonoses are infectious diseases transmitted directly or indirectly between animals and humans. Several important zoonotic pathogens colonize farm animals asymptomatically, which may lead to contamination of the food chain and public health hazards. Moreover, routine sampling of carcasses at retail by government authorities over the past 20 years suggests the prevalence of antibiotic resistance in foodborne pathogens has increased. If this continues, antibiotics may be ineffective against such pathogens in the future and alternative approaches, such as phage therapy, may be necessary. Intensive livestock farming is the only realistic way of meeting the demand for meat from an increasing global population and growth in middle class consumers in developing countries, particularly in Asia. This review elaborates on the use of phages to control zoonotic pathogens in intensively-reared livestock (poultry and pigs).
\end{abstract}

Keywords: Bacteriophage, Zoonotic, Phage therapy

\section{Background}

\section{Poultry and pig intensive farming}

A significant increase in meat production will be required over the coming decades in order to meet demand from a growing global population and greater income and dietary choice in developing countries [1]. So far, much of this demand has been met by intensive livestock farming, particularly poultry and pigs. Unfortunately, such production systems can facilitate disease transmission as these animals often have low genetic diversity and are reared in large and dense populations [2]. The Food and Agricultural Organization (FAO) reported that between 1961 and 2016, world poultry meat production increased from 9 to 120 million tonnes, and egg production grew from 15 to 81 million tonnes [3]. The most recent FAO meat market review report estimated that poultry and pig meat production was 123.9 and 120.5 million tonnes respectively in 2018 [4]. In many parts of the world, antimicrobials are used in intensive farming for growth promotion, disease prevention, or therapy which may select for populations of antibioticresistant pathogens [2]. In the USA in 2012, animals consumed $70 \%$ of medically important antibiotics $(8.9$

\footnotetext{
* Correspondence: robert.atterbury@nottingham.ac.uk

School of Veterinary Medicine and Science, University of Nottingham, Sutton Bonington, Leicestershire LE12 5RD, UK
}

tons) [5]. In China, the livestock industry will use up to $30 \%$ of global antimicrobial production by 2030 [6]. The emergence of antimicrobial resistance in bacterial pathogens will inevitably result in treatment failure, increased pathogen transmission and concomitant production losses [7].

\section{Bacterial zoonoses and intensively-reared livestock}

The most common zoonotic bacterial pathogens associated with poultry and pigs are Salmonella spp., E. coli, Campylobacter spp., Clostridium spp. and Listeria spp. [8, 9]. The most recent European Food Safety Authority (EFSA) report states that these pathogens are often resistant to several antibiotics $[9,10]$. In the EU, the official data about zoonotic and indicator bacteria from humans, animals and food show high proportions $(28.6 \%$ out of more than 8000) of human Salmonella isolates were resistant to three or more antimicrobials [10]. Additionally, 34.9\% of indicator isolates of $E$. coli from fattening pigs were multidrug resistant [10]. The pipeline for developing new antibiotics to counter this resistance is running dangerously low on new candidate molecules [11] and alternative approaches are urgently needed. One option is the use of lytic bacteriophages to combat bacterial diseases in livestock [12]. A review sponsored by the UK Department of Health and the Wellcome Trust reported that, of the top 
10 most promising alternatives to antibiotics, three were based on using bacteriophages or their components [13].

Bacteriophages were discovered in the early twentieth century by Twort (1915) and d'Herelle (1917) while working independently in the UK and France, respectively [14]. D'Herelle [15] first tested phage therapy in animals, with the successful treatment of fowl typhoid in chickens (95-100\% survival of phage-treated birds compared with 0-25\% for untreated controls). Pyle [16] reported using phage to treat chickens with a systemic Salmonella infection caused by Salmonella enterica serotype Pullorum. While the phage demonstrated marked bacteriolysis in vitro; when used in vivo they did not reduce mortality or have much therapeutic effect. Following the discovery of antibiotics in the 1920s, little work was done in the West using phage to treat infections of livestock until Williams Smith's pioneering studies of the 1980s. For a more extensive review of the history of phage use in agriculture and animals, see the review by Sulakvelidze and Barrow [17]. The following sections summarise findings from more recent phage therapy studies in poultry and pigs.

\section{Main text}

\section{Salmonellosis}

Salmonella is a common target for phage therapy because it causes disease in a wide range of endothermic animals as well as humans and causes significant production losses in livestock. Some Salmonella serotypes (e.g. S. enterica serotype Typhi) are known as 'host-restricted' because they produce a severe, systemic, typhoid-like illness in a single host (or small number of related hosts). However, phage therapy has mainly focussed on 'non-host-restricted' serotypes (principally Enteritidis and Typhimurium) which usually result in a less severe gastrointestinal infection across a much broader range of species and lead to most foodborne bacterial infections in developed countries $[17,18]$.

Phage therapy has been used to control Salmonella in chickens with varying degrees of success. Sklar et al. used phages in a broiler chick model to demonstrate that Salmonella colonization of the cecum could be significantly reduced by almost $1 \log _{10}$ Colony Forming Units (CFU)/g gut contents over 14-days by administering a cocktail of four phages in feed $\left(10^{9}\right.$ Plaque Forming Units (PFU)/g) [19]. Additionally, phage treatment appeared to reduce secondary infection signs in the birds as only three out of 10 animals in the phagetreated group showed mild inflammation on the air sacs while 8 out of 10 birds in the untreated control group showed signs of airsacculitis. Fiorentin et al. demonstrated that a single oral dose of three phages each at $10^{11}$ PFU could reduce $S$. Enteritidis colonisation of broiler chickens by $3.5 \log _{10} \mathrm{CFU} / \mathrm{g}$ in the broiler chicken caecum when exposed to 7-days-old seeder chicks infected with $10^{8} \mathrm{CFU}$ of $S$. Enteritidis [20].

Atterbury et al. [21] selected three lytic phage (isolated from poultry farms and wastewater in the UK) with a broad host range against $S$. Enteritidis, $S$. Hadar and $S$. Typhimurium. A $9.0 \log _{10}$ PFU suspension of each phage was used to treat 36-day-old Ross broiler chickens which had been separately infected with the three different serotypes. All of the phages tested reduced Salmonella colonisation of the ceca, although only $S$. Enteritidis and $S$. Typhimurium were reduced significantly; by approximately $2.19-2.52 \log _{10} \mathrm{CFU} / \mathrm{g}$ compared with the controls. Bacteriophage-insensitive mutants (BIMs) were recovered from phage-treated animals. However, this phage-resistant phenotype was not maintained in vitro following successive subculturing, nor in vivo when BIMs were introduced into a new group of birds in the absence of phage selective pressure.

Lim et al. demonstrated how phage could be used to prevent horizontal infection by Salmonella Enteritidis in a commercial layer chick seeder model [22]. Groups of 1 -day-old chicks were challenged with $5 \times 10^{11} \mathrm{CFU}$ of Salmonella Enteritidis and for the next 21 days cohabitated with uninfected contact chicks while being treated in three independent groups with one of three titres $\left(10^{5}, 10^{7}\right.$ or $\left.10^{9} \mathrm{PFU} / \mathrm{g}\right)$ of bacteriophage prepared as a feed additive. All the treatments significantly $(P<0.05)$ reduced the intestinal colonization by up to $1 \log _{10}$ $\mathrm{CFU} / \mathrm{g}$ at the end of the 21 days, with $70 \%$ of the contact chickens treated with the highest phage titre having no detectable Salmonella Enteritidis colonization. Borie et al. [23] administered a combination of three Salmonella-specific phages $\left(10^{8} \mathrm{PFU} / \mathrm{mL} /\right.$ dose $)$ via coarse spray or drinking water on 10 -day-old chicks $24 \mathrm{~h}$ before the experimental challenge with $9.6 \times 10^{5} \mathrm{CFU} S$. Enteritidis. Phage delivery both by coarse spray and drinking water significantly reduced the mean intestinal $S$. Enteritidis counts by up to $1.6 \log _{10} \mathrm{CFU} / \mathrm{mL}$.

Ahmadi et al. [24] determined the ability of phages to reduce $S$. Enteritidis in the ceca of Japanese quails. Phage 'PSE' was administered to groups of 8-day-old quail by oral gavage either prophylactically $\left(10^{5} \mathrm{PFU}\right)$ three days before challenge with $10^{8} \mathrm{CFUS}$. Enteritidis; or therapeutically immediately after $S$. Enteritidis challenge. Prophylactic administration reduced the detection of Salmonella in the ceca to 33.3 and 20\%, 24 h and 7 days after PSE administration, respectively, while in the infected control group all birds tested positive for $S$. Enteritidis in the cecal tonsils. No such reduction was recorded in the birds treated therapeutically. In a further experiment, groups of 1-day-old quail were treated with $10^{8}$ PFU of phage PSE daily for six days, either by oral gavage or vent lip. On day four, these birds were challenged with $10^{8} \mathrm{CFU}$ of $\mathrm{S}$. Enteritidis. Salmonella was detected in the 
ceca of birds treated orally with phage PSE $6 \mathrm{~h}$ following Salmonella challenge, but not subsequently up to 35 days post challenge. Some birds (up to 2 out of 8 ) treated with phage PSE via the vent lip periodically tested positive for $S$. Enteritidis throughout the study period, but the majority remained free of $S$. Enteritidis.

Besides the application in poultry, the effect of phage cocktails against Salmonella in pigs has also been demonstrated. Wall et al. [25] administered $5 \times 10^{9} \mathrm{CFU}$ of $S$. Typhimurium $\gamma 4232$ and, simultaneously, microencapsulated alginate beads containing $5 \times 10^{9} \mathrm{PFU}$ of 16 phages mixed as cocktail, to 3 to 4 week old pigs by gavage. The authors reported a 2 to $3 \log _{10} \mathrm{CFU} / \mathrm{g}$ reduction in the Salmonella counts in the ileum, caecum and tonsils. In a different experimental design, marketweight pigs were challenged with $5 \times 10^{9} \mathrm{CFU} S$. Typhimurium orally and then treated with $10^{10} \mathrm{PFU}$ of microencapsulated phage cocktail $48 \mathrm{~h}$ later (administered orally three times, with $2 \mathrm{~h}$ interval between doses) followed by comingling with Salmonella-infected seeder pigs. Salmonella average cecal counts in the phagetreated pigs were significantly reduced by $1.4 \log _{10}$ $\mathrm{CFU} / \mathrm{mL}$ compared with untreated controls.

Saez et al. [26] administered a bacteriophage cocktail as a microencapsulated feed additive and demonstrated it can be an effective and practical way of reducing Salmonella colonization and shedding in pigs. The experimental design comprised 21 pigs randomly separated into three groups. Group 1 was given a feed additive containing a microencapsulated phage cocktail $\left(5 \times 10^{11} \mathrm{PFU}\right.$ per day $)$ for 5 days before being orally challenged with $5 \mathrm{~mL}$ of $10^{9}$ CFU/mL Salmonella Typhimurium. Group 2 was given $60 \mathrm{~mL}$ of the phage cocktail $\left(5 \times 10^{11} \mathrm{PFU}\right)$ every $2 \mathrm{~h}$ after the challenge, during a total of $6 \mathrm{~h}$. Group 3 received no phage treatment, and all groups were orally challenged on the fifth day with $5 \mathrm{~mL}$ of $10^{9} \mathrm{CFU} / \mathrm{mL} S$. Typhimurium bacterial suspension. The results showed lower faecal shedding of $S$. Typhimurium at $2 \mathrm{~h}$ post challenge (group $1=38.1 \%$, group $2=71.4 \%$, group $3=71.4 \%, P<0.05$ ) and $4 \mathrm{~h}$ post challenge (group $1=42.9 \%$, group $2=81.1 \%$, group $3=85.7 \%, P<0.05$ ) when the phage cocktail was administered as a feed additive. Additionally, $S$. Typhimurium counts in ileal and cecal contents were $1 \log _{10} \mathrm{CFU} / \mathrm{g}$ lower in the phage-treated feed additive group compared with the control group.

Seo et al. [27] determined the therapeutic potential of a bacteriophage cocktail which was able to kill 34 reference strains and 99 isolates (107 tested) of S. Typhimurium. Groups of four-week-old pigs were given $5 \mathrm{~mL}$ of a phage cocktail at $10^{9} \mathrm{PFU} / \mathrm{mL}$ until the end of the study (15 days) and at day 7 were challenged with $10 \mathrm{~mL}$ of $S$. Typhimurium (ATCC140828) at $10^{8} \mathrm{CFU} / \mathrm{mL}$. No Salmonella shedding was detected in the fecal samples 7 days post infection in the phage treated group compared with a mean colonisation of $1.0 \log _{10} \mathrm{CFU} / \mathrm{mL}$ for the untreated control group.

The administration of Salmonella phages orally exposes them to potentially hostile conditions, such as low $\mathrm{pH}$ of the stomach/gizzard and the activities of bile and enzymes in the duodenum, which may impact bacteriophage viability. Various approaches have been used to mitigate against the potential damage which these conditions may cause, including concomitant administration of antacid [21], microencapsulation with chitosan/alginate [28] microencapsulation with alginate [29], microencapsulation with antacid/alginate [30] and liposome nanoencapsulation [31].

\section{Colibacillosis}

Pathogenic strains of Escherichia coli in poultry are the causal agent of colibacillosis which is responsible for considerable mortality in poultry. E. coli colonization of the avian respiratory tract may progress down to the air sacs causing septicaemia and ultimately death [32]. In broiler chickens, Huff et al. [33] demonstrated the efficacy of administering a high titre mixture of phage by spray to reduce colibacillosis-associated mortality. In this model, high titres of two phage (SPR02, $2.6 \times 10^{8} \mathrm{PFU} /$ $\mathrm{mL}$ and DAF6, $2.35 \times 10^{9} \mathrm{PFU} / \mathrm{mL}$ ) were administered by spray at day 7 , followed by challenge with a pathogenic E. coli injected directly into the thoracic air sac $\left(5.6 \times 10^{4} \mathrm{CFU}\right)$ at day 7,8 or 10 . Phage treatment resulted in a significant reduction in mortality which was most pronounced when the phage were administered at the same time as the bacterial challenge (30\% mortality vs $60 \%$ mortality for untreated control birds). Noteworthy, one experimental group of birds was found to be already infected with $E$. coli which was susceptible to lysis by phage SPR02. The authors suspected that this was due to a naturally-occurring infection, though this was not confirmed. These birds had a slight lower hatch weight, and a significantly higher mortality in the untreated control group (20\%) and buffer spray control group (27\%) compared with the phage treated group (3\%). This suggested that phage administration might have provided therapeutic treatment for the pre-existing colibacillosis.

Huff et al. [34] again used phage SPR02 in a different phage therapy model. Groups of ten 3-day-old chicks were challenged with $10^{3}$ to $10^{4} \mathrm{CFU}$ of $E$. coli by direct injection into the air sacs. One group was administered phage $\left(10^{3}\right.$ or $\left.10^{6} \mathrm{PFU}\right)$ simultaneously with the E. coli, the second group was administered phage via drinking water. Administration of phage via drinking water had no protective effect, whereas simultaneous injection was associated with a reduced mortality ( $25 \%$ or $5 \%$ for birds treated with $10^{3}$ and $10^{6}$ PFU respectively). This compared favourably with $80 \%$ mortality recorded for the 
untreated control group. However, the mixing of phage and host during administration is likely to produce artificially positive results, as the phage will have the opportunity to infect and replicate within the bacteria before they have a chance to establish an infection; effectively reducing the challenge.

Huff et al. [35] again used phages SPR02 and DAF6 to treat colibacillosis, this time by aerosol spray or intramuscular injection. The challenge used $5.96 \times 10^{4} \mathrm{CFU}$ of $E$. coli injected in the left thoracic air sac of 7-day-old chicks. The phage treatment using the aerosol spray $\left(7.65 \times 10^{8}\right.$ and $2.83 \times 10^{9} \mathrm{PFU} / \mathrm{mL}, \mathrm{DAF} 6$ and SPR02, respectively) provided significant protection to the birds as shown by the low mortality of the treated group (20\%) when compared to the control group (50\%). However, if phage treatment was delayed by 24 or $48 \mathrm{~h}$ after bacterial challenge, no therapeutic benefit was observed. Conversely, birds treated with a combination of phages $\left(1.88 \times 10^{9}\right.$ and $6.35 \times 10^{8} \mathrm{PFU} / \mathrm{mL}$ of DAF6 and SPR02, respectively) by intramuscular injection had a significantly lower mortality $(\leq 20 \%)$ compared with the control group (53\%) whether phage were administered immediately or up to $48 \mathrm{~h}$ after bacterial challenge. These results reinforce the notion that the administration route plays a fundamental part in the phage therapy outcome, as the best results appear to be achieved by injecting phage into the birds, which given the nature of poultry farming in unlikely to offer a practical solution to colibacillosis.

Huff et al. [36] evaluated the potential synergy of antibiotics and phage treatment for colibacillosis. Groups of ten seven-days-old chicks were challenged with $6 \times 10^{4}$ CFU of $E$. coli injected into the left thoracic air sac. This was followed immediately by injection of one of two phages directly into the thigh muscle $\left(3.7 \times 10^{9}\right.$ and $9.3 \times 10^{9}$ PFU per $\mathrm{mL}$ of phages DAF6 or SPR02, respectively). Enrofloxacin was introduced into the birds' drinking water at $50 \mathrm{ppm}$ for 7 consecutive days, starting immediately after $E$. coli challenge. High mortality (68\%) was recorded for the untreated control group. This compared with $15 \%$ mortality in the phage-treated group, 3\% mortality in the enrofloxacin-treated group and $0 \%$ for birds treated with both phage and antibiotic. This led the authors to suggests the occurrence of synergy between both therapeutic agents when used in combination with improved efficacy.

Oliveira et al. [37] tested phage delivery using a fine drop scatter spray in experimentally and naturally infected chickens. Groups of twelve 10-week-old Rhode Island Red chickens were challenged with $1 \times 10^{8} \mathrm{CFU}$ of avian pathogenic E. coli $\mathrm{H} 839 \mathrm{E}$, by injection in the left thoracic air sac. The phage-treated group was given a suspension of $1.5 \times 10^{9} \mathrm{PFU}$ phi F78E, orally and by spray. The results showed a significantly $(P<0.05)$ lower pathology score $(\approx 2.5)$, morbidity $(\approx 60 \%)$ and mortality $(\approx 45 \%)$ in the phage-treated group when compared to the untreated control pathology $(\approx 4)$, morbidity $(\approx 100 \%)$ and mortality $(\approx 75 \%)$ scores. Moreover, the average mortality was $25.0 \%$ lower, the average morbidity $41.7 \%$ lower, and the lesions found in carcasses were also less severe in the phage-treated group, when compared with the untreated controls.

El-Gohary et al. [38] tested the spray delivery of phages onto litter as a means to reduce colibacillosis. The surface of the litter in $3.9 \mathrm{~m}^{2}$ pens was sprayed with $200 \mathrm{~mL}$ of a $2.8 \times 10^{8} \mathrm{CFU} / \mathrm{mL}$ of a culture of pathogenic E. coli. For phage-treated groups, the pens were immediately sprayed with $200 \mathrm{~mL}$ of a $8 \times 10^{8} \mathrm{PFU} / \mathrm{mL}$ suspension of phage SPR02. The mortality of the control and the phage-treated groups was 25 and 5\%, respectively. The authors suggest that sanitising the environment with phages reduces the level of the target pathogen to below the infectious dose, hindering the onset of bacterial diseases, and claim it is a practical and efficacious way to prevent colibacillosis in broiler chickens. However, the metabolic state of in vitro cultured bacteria, such as those sprayed on litter, may differ substantially from sub-lethally injured cells which may be found naturally in the farm environment. As such, it may be difficult to repeat these results in a real poultry farm scenario.

Besides respiratory infections in poultry, colibacillosis in a meningitis and septicaemia model were addressed in poultry with a phage therapy approach [39]. The experimental design used 3-week-old Rhode Island Red chickens infected with $E$. coli $\mathrm{H} 247 \mathrm{~K} 1+$ via intramuscular or intracranial administration, followed by an intramuscular injection of phage $\mathrm{R}$ at $10^{4}$ or $10^{6}$ PFU. Mortality in the phage treated groups was zero, compared with $100 \%$ in the untreated control group. None of the birds treated with phage exhibited clinical signs of infection. Moreover, delaying phage treatment until clinical signs of disease were evident still led to considerable protection as all 10 untreated control birds died compared with 3 out of 10 for the phage-treated group. Prophylactic administration of phage up to two days before bacterial challenge was also effective in reducing mortality to 1 out of 9 in the phage treated group compared with 4 out of 9 in the control group. Phage $\mathrm{R}$ was able to multiply in the blood and penetrate the blood-brain barrier. Together, this data supports the idea that even acute infections might be amenable to phage treatment.

Pioneering work in phage therapy addressing colibacillosis in pigs (and also mice, cattle and sheep) was performed in the 1980s by Smith and Huggins [40-42]. In one study, diarrhoea was induced in piglets by giving them $3 \times 10^{8} \mathrm{CFU}$ of pathogenic E. coli O20:K101 987P to seven piglets and 13-16 h later they were treated by oral administration of a mixture $\left(10^{10} \mathrm{PFU}\right)$ of two 
phages (P433/1 and $\mathrm{P} 433 / 2)$ or a single phage (P433/1). Symptoms of disease in phage-treated piglets ceased 18$22 \mathrm{~h}$ later, while the challenged untreated piglets were severely ill, markedly dehydrated, ataxic, mentally confused and if they had not been fed by stomach tube, the authors claim the whole group of seven piglets would have died [41].

Jamalludeen et al. [43] showed a beneficial effect of phages on weaned pigs infected with an enterotoxigenic E. coli O149:H10:F4. The pigs were inoculated orally by syringe with $10^{10} \mathrm{CFU}$ of $E$. coli, followed by treatment with six phages (GJ1-GJ7) either individually or combined in a dose of $10^{9} \mathrm{PFU}$ of each phage. These phages were administered either prophylactically ( $15 \mathrm{~min}$ after challenge) or therapeutically ( $24 \mathrm{~h}$ after challenge). The antibiotic florfenicol was used prior to the bacterial challenge in an attempt to enhance $E$. coli colonization. The prophylactic use of the six phages individually significantly reduced the duration and severity of the diarrhoea as shown by the clinical symptom score of $<4$ when compared with $\approx 10$ from the challenged control. Moreover, the therapeutic administration of a two phage cocktail significantly reduced the symptoms, the development of diarrhoea and the shedding of the pathogenic E. coli without changes to the commensal E.coli numbers [43]. The usage of bacteriophages as an in-feed additive for pigs, administered prophylactically, was regarded as safe as it had no adverse immunological effects, and may also result in improved weight gain [44-47].

\section{Campylobacteriosis}

Campylobacter spp. is the most significant cause of acute bacterial food borne disease in the EU [48]. Approximately $95 \%$ of all reported cases result from infection with one species, C. jejuni. Campylobacter is highly adapted to the colonisation of the avian gut and has a relatively low infectious dose for humans (thought to be approximately 500 cells [49]). There is a host immune response, manifest by the sIgA antibodies titre, however it has little to no effect on the level of colonization of $C$. jejuni in broilers [50]. High counts of Campylobacter bacteria on broiler caeca may result in carcass contamination at the abattoir. It has been calculated that a reduction of Campylobacter counts on carcasses by $2 \log _{10}$ may result in a 30-fold decrease in human campylobacteriosis [51]. The antibiotic resistance profile of 486 campylobacters isolated from retail chickens by the UK Food Standards Agency from 2016 to 17 found resistance to ciprofloxacin (251), tetracycline (322), nalidixic acid (247), streptomycin (18) and erythromycin (2). Multidrug resistance to three or more antibiotics was recorded for 17 isolates [52]. These results stress the need for an effective solution to deal with contamination of poultry carcasses with Campylobacter.
Wagenaar et al. [53] determined whether a phage preparation administered by oral gavage (from day 7 to 16) could protect 10-day-old Ross broiler chicks or adult chickens from a challenge with $C$. jejuni $\left(10^{5} \mathrm{CFU} / \mathrm{mL}\right.$ on day 10). The phage preparation did not show any protective effect in the birds, however, when administered after the bacterial challenge, a $3 \log _{10} \mathrm{CFU} / \mathrm{g}$ reduction in the counts of $C$. jejuni was observed in the caeca of phagetreated birds. Loc-Carrillo et al. [54] selected two phages (CP8 and CP34) from a panel of 53 isolated from chicken faeces to use as candidates to reduce Campylobacter in chickens. The phages were selected on the basis of favourable in vitro replication kinetics and a broad host range. Ross broiler chickens were experimentally infected with $C$. jejuni isolates HPC5 and GIIC8 at various doses (from 2.7 to $7.8 \log _{10} \mathrm{CFU}$ ) by oral gavage at 18 to 20 days of age. A single phage treatment (5-9 $\log _{10}$ PFU) was administered at 25 days of age by oral gavage. C. jejuni counts in the upper intestine and ceca of phage-treated birds were reduced by between 0.5 and $5 \log _{10} \mathrm{CFU} / \mathrm{g}$ when phages were applied at $\geq 10^{7}$ PFU. Phage-resistant $C$. jejuni isolates were recovered from phage-treated birds (4\%) but this was markedly lower than recovery of resistant isolates from in vitro studies (11\%). The authors suggested that, in the absence of phage selective pressure, phage-resistant mutants may colonise the chicken gut less effectively. This interpretation is supported by the authors' observation that when phage-resistant isolates are used to challenge birds in the absence of phage, $97 \%$ of campylobacters reverted to a phage-sensitive phenotype [54]. In a previous study, the same group showed that in 90 UK broiler flocks, counts of $C$. jejuni in the presence of naturally occurring bacteriophages were lower when compared to samples where phage could not be detected (5.1 vs 6.9 $\log _{10} \mathrm{CFU} / \mathrm{g}$ respectively) [55].

Lytic phages that infect Campylobacter have been categorized into three groups (I to III) based on the structure, genome size and receptor used to infect the host [56]; and phages from group II and II apparently use multiple host cell receptors for binding [57-59]. ElShibiny et al. [60] recorded a $2 \log _{10}$ CFU/g reduction in caecal counts of Campylobacter HPC5 $48 \mathrm{~h}$ after administering a single $10^{7} \mathrm{PFU}$ dose of group II bacteriophage $\mathrm{CP} 220$. The incidence of phage resistance in colonized chickens after phage treatment was shown to be residual, only around $2 \%$ of the population [60]. More recently, Hammerl et al. [61] used a combined treatment of group II and III phages. Groups of 20-day-old male Vrolix chicks were inoculated with $10^{9} \mathrm{CFU}$ of $C$. jejuni. After 7 days the infected birds were administered a phage suspension of $5 \times 10^{8} \mathrm{PFU}$ of CP14 (group III), CP81 (group III) or CP68 (group II) either alone or combined. At 31 days of age the experimental birds were euthanised and the $C$. jejuni counts in caeca revealed a $1 \log _{10} \mathrm{CFU} / \mathrm{g}$ 
reduction in cecal colonisation when treated with CP14 alone, compared with the control group. The addition of CP81 to CP14 did not improve this reduction. However, a $3 \log _{10} \mathrm{CFU} / \mathrm{g}$ reduction was recorded when treatment with CP14 was followed by CP68 the next day. The authors claim the different host receptors used by group II and III phages are the underlying reason for both the significant reduction in Campylobacter counts and also for the lower levels of resistant isolates obtained when using a mixture group II and III phages (3\%) when compared to the single CP14 phage (4\%) or two phages from the same group III (8\%).

As Campylobacter colonizes the caeca in birds, and does not appear to be very invasive, phage are usually administered orally. Carvalho et al. [62] found that the administration of a cocktail of three phages to broiler chickens by gavage and feed reduced $C$. jejuni and $C$. coli colonisation in broiler chicken faeces by approximately $2 \log _{10} \mathrm{CFU} / \mathrm{g}$. The authors report the counts of Campylobacter were maintained $1 \log _{10}$ CFU lower in the phage-treated group when compared to the untreated control. However, phage resistant isolates recovered from faeces (13\%) did not show a reduced ability to colonize the chicken guts or revert to a phage-sensitive phenotype. More recently, the impact on the microbiota of broiler chickens infected with Campyobacter jejuni HPC5 after treatment with a two phage cocktail was determined [63]. The authors showed a $2 \log _{10} \mathrm{CFU} / \mathrm{g}$ reduction on the Campylobacter counts in cecal content, that in vivo the phages replicate and maintained as a stable population and, additionally, the infection of $C$. jejuni by the phages tested did not affect the microbiota [63].

\section{Clostridiosis}

Clostridium perfringens is the causal agent of necrotic enteritis, a disease that affects chickens and whose pathogenesis is incompletely understood. The involvement of toxins and hydrolases secreted by the bacterium are thought to be relevant for the virulence and intestinal colonization by the anaerobic C. perfringens [64]. Additionally, parasites of Eimeria species that colonize the small intestine, such as Eimeria maxima and Eimeria acervulina, are known to predispose to necrotic enteritis by leaking of plasma to the intestinal lumen which provides a necessary growth substrate for extensive proliferation of Clostridium perfringens [65]. Phage treatments have shown some efficacy in reducing the symptoms and disease progression in chickens. In a study using a total of 900 birds in various experimental designs, Miller et al. [66] showed that oral administration of a five phage cocktail at $10^{5} \mathrm{PFU} / \mathrm{mL}$ by oral gavage or drinking water to experimentally infected Cobb broiler chickens ( 0 to 42-days old) with C. perfringens resulted in a $92 \%$ reduction in mortality compared with the untreated control group. Additionally, the authors conclude that in the 0-42 days period, the specific cocktail used (INT$401)$ increased weight gain and feed conversion ratios in both the phage-in-water group $(2.618 \pm 0.059 \mathrm{~kg})$ and phage-in-feed group $(2.547 \pm 0.059 \mathrm{~kg})$ when compared to the challenged untreated group $(2.296 \pm 0.059 \mathrm{~kg})$, and may be an effective therapy to control the necrotic enteritis caused by $C$. perfringens.

C. perfringens is a Gram-positive bacterium, this implies that the thick peptidoglycan layer is the outmost barrier exposed to the environment. The phageencoded endolysins, enzymes that target and hydrolyse specific bonds within the peptidoglycan mesh, have been reported to suffice to achieve bacterial lysis [67]. The usage of purified endolysins from phages that target $C$. perfringens is shown as a promising route to reduce the colonization or treat the infection by this pathogen as has been described and subject of review elsewhere [8, 68-70].

\section{Conclusions}

The emergence of antibiotic resistant zoonotic pathogens in the food chain is a growing public health problem worldwide. The lack of new antibiotics coming onto the market necessitates development of alternative strategies to deal with these bacteria. Bacteriophages were used in veterinary applications soon after their discovery more than a century ago. Whilst the efficacy of phage therapy varies according to the bacterial target and complexity and location of the infection site(s), most recent studies in intensively-reared livestock have found that these pathogens can be significantly reduced using phages. This may have a beneficial effect on both animal and human health, and in some instances may lead to greater productivity of the industry. Highlyintegrated production systems, found in the poultry industry for example, are more amenable to phage therapy, as a single company can control all aspects of meat production before the point of retail sale. Potentially, this allows the flexibility to introduce phage at various points, from feed/water or sprays at the farm level to wash treatments and modified packaging at the abattoir. However, in the EU there is no regulatory framework which would allow such interventions. Bacteriophage do not fit easily into existing EU regulations regarding the use of food additives or food processing aids, which is a significant obstacle.

The emergence of phage-resistant bacterial pathogens is a threat analogous to the development of antibiotic resistance. However, resistance to one phage does not necessarily result in resistance to others, and there appears to be a fitness cost to resistance in the absence of phage, at least in some cases. These factors will be 
important when designing phage interventions in the future, which may comprise cocktails targeting several different receptors, thus minimising the probability of resistance emerging. In this context, pathogens which are more genetically homogeneous, such as Staphylococcus aureus, may be more attractive targets for phage therapy than genetically diverse hosts such as E. coli, as fewer phage will be needed to cover the range of clinical strains circulating in a population at any point in time. This may also influence the overall phage treatment strategy as phage deployed prophylactically, rather than therapeutically, against bacteria such as E. coli are less likely to result in success than for Staphylococcus aureus. Also, whilst entry of phage into the wider environment may be more controllable in intensively-reared livestock, some release is inevitable and may necessitate the regular reformulation or cycling of cocktails in order to circumvent resistance and maintain efficacy. Given the challenges of meeting the growing demand for meat over the next century, viable alternatives to antibiotics will be needed to control disease in increasingly intensifying production systems. However, like antibiotic chemotherapy and vaccination, this is unlikely to offer a panacea.

\section{Abbreviations}

BIM: Bacteriophage-insensitive mutants; CFU: Colony Forming Units;

EFSA: European Food Safety Authority; FAO: Food and Agricultural

Organization; PFU: Plaque Forming Units

\section{Acknowledgements}

Not applicable.

\section{Authors' contributions}

Both authors contributed equally to the writing of this manuscript. Both authors read and approved the final manuscript.

\section{Funding}

Not applicable.

\section{Availability of data and materials}

Not applicable.

\section{Ethics approval and consent to participate}

Not applicable.

\section{Consent for publication}

Not applicable.

\section{Competing interests}

The authors declare that they have no competing interests.

Received: 7 June 2019 Accepted: 22 November 2019

Published online: 12 December 2019

\section{References}

1. Delgado CL, Rosegrant MW, Steinfeld H, Ehui SK, Courbois C. Livestock to 2020 : the next food revolution [Internet]: International Food Policy Research Institute; 1999. Available from: https://hdl.handle.net/10568/333. Accessed 7 June 2019

2. Jones BA, Grace D, Kock R, Alonso S, Rushton J, Said MY, et al. Zoonosis emergence linked to agricultural intensification and environmental change. Proc Natl Acad Sci. 2013;110(21):8399-404. Available from: http://www.pnas. org/cgi/doi/10.1073/pnas.1208059110.
3. Food and Agriculture Organization of the United Nations (FAO). Gateway to poultry production and products [Internet]. 2019. Available from: http://www. fao.org/poultry-production-products/production/en. Accessed 7 June 2019.

4. Food and Agriculture Organization of the United Nations (FAO). Meat Market Review [Internet]. 2019. Available from: http://www.fao.org/3/ca3 880en/ca3880en.pdf. Accessed 7 June 2019.

5. O'Neill J. Tackling drug resistant infections globally: final report and recommendations [Internet]. 2016. Available from: https://amr-review.org/ sites/default/files/160518_Final\%20paper_with\%20cover.pdf. Accessed 7 June 2019.

6. Van Boeckel TP, Brower C, Gilbert M, Grenfell BT, Levin SA, Robinson TP, et al. Global trends in antimicrobial use in food animals. 2015; Available from: www.pnas.org/cgi/doi/10.1073/pnas.1503141112.

7. Nhung NT, Chansiripornchai N, Carrique-Mas JJ. Antimicrobial resistance in bacterial poultry pathogens: a review. Front Vet Sci. 2017:4:126. Available from: http://journal.frontiersin.org/article/10.3389/fvets.2017.00126/full.

8. Wernicki A, Nowaczek A, Urban-Chmiel R. Bacteriophage therapy to combat bacterial infections in poultry. Virol J. 2017;14(1):179. Available from: http:// www.ncbi.nlm.nih.gov/pubmed/28915819.

9. European Food Safety Authority (EFSA). The European Union Summary Report on Trends and Sources of Zoonoses, Trends and Sources of Zoonoses, Zoonotic Agents and Food-borne Outbreaks in 2017 [Internet]. 2018. Available from: https://efsa.onlinelibrary.wiley.com/doi/epdf/10.2903/j. efsa.2018.5500. Accessed 7 June 2019.

10. European Food Safety Authority (EFSA). The European Union summary report on antimicrobial resistance in zoonotic and indicator bacteria from humans, animals and food in 2017. EFSA Journal. 2018;17(2):e05598.

11. Burki T. Antibiotic development pipeline slows to a trickle. Lancet Infect Dis. 2017;17(11):1128-9. Available from: https://www.sciencedirect.com/science/ article/pii/S1473309917305868?via\%3Dihub.

12. Fernández L, Gutiérrez D, Rodríguez A, García P. Application of bacteriophages in the agro-food sector: a long way toward approval. Front Cell Infect Microbiol. 2018;8:1-5. Available from: https://www.frontiersin.org/ article/10.3389/fcimb.2018.00296/full.

13. Czaplewski L, Bax R, Clokie M, Dawson M, Fairhead H, Fischetti VA, et al. Alternatives to antibiotics-a pipeline portfolio review. Lancet Infect Dis. 2016; 16(2):239-51. Available from: http://www.ncbi.nlm.nih.gov/pubmed/26795692.

14. Duckworth DH. Who discovered bacteriophage? Bacteriol Rev. 1976;40(4): 793-802. Available from: https://www.ncbi.nlm.nih.gov/pmc/articles/PMC413 985/pdf/bactrev00054-0007.pdf.

15. d'Herelle F. Sur le role du microbe bacteriophage dans la typhose aviare. C R Acad Sci. 1919;169:932-4.

16. Pyle NJ. The bacteriophage in relation to Salmonella Pullorum infection in domestic fowl. J Bacteriol. 1926;12(4):245-61. Available from: http://www. ncbi.nlm.nih.gov/pubmed/16559213.

17. Sulakvelidze A, Barrow P. Phage therapy in animals and agribusiness. In: Kutter E, Sulakvelidze A, editors. Bacteriophages: biology and applications. Boca Raton: CRC Press; 2005. p. 335-80.

18. Sanderson KE, Nair S. Taxonomy and species concepts in the genus Salmonella. In: Barrow PA, Methner U, editors. Salmonella in domestic animals. 2nd ed. Wallingford: CAB International; 2013. p. 1-19. Available from: http://www.cabi.org/cabebooks/ebook/20133229790.

19. Sklar IB, Joerger RD. Attempts to utilize bacteriophage to combat salmonella enterica serovar enteritidis infection in chickens. J Food Safety. 2001;21(1):15-29. Available from: https://onlinelibrary.wiley.com/doi/abs/1 0.1111/j.1745-4565.2001.tb00305.x.

20. Fiorentin L, Vieira ND, Barioni W Jr. Oral treatment with bacteriophages reduces the concentration of Salmonella Enteritidis PT4 in caecal contents of broilers. Avian Pathol. 2005;34(3):258-63. Available from: http://www.ncbi. nlm.nih.gov/pubmed/16191711.

21. Atterbury RJ, Van Bergen MAP, Ortiz F, Lovell MA, Harris JA, De Boer A, et al. Bacteriophage therapy to reduce Salmonella colonization of broiler chickens. Appl Environ Microbiol. 2007;73(14):4543-9. Available from: http:// www.ncbi.nlm.nih.gov/pubmed/17526794.

22. Lim T-H, Kim M-S, Lee D-H, Lee Y-N, Park J-K, Youn H-N, et al. Use of bacteriophage for biological control of Salmonella Enteritidis infection in chicken. Res Vet Sci. 2012;93(3):1173-8. Available from: http://www.ncbi.nlm. nih.gov/pubmed/22795674.

23. Borie C, Albala I, Sànchez P, Sánchez ML, Ramírez S, Navarro C, et al. Bacteriophage treatment reduces Salmonella colonization of infected chickens. Avian Dis. 2008;52(1):64-7. 
24. Ahmadi M, Karimi Torshizi MA, Rahimi S, Dennehy JJ. Prophylactic bacteriophage administration more effective than post-infection Administration in Reducing Salmonella enterica serovar Enteritidis shedding in quail. Front Microbiol. 2016;7:1253. Available from: http://www.ncbi.nlm. nih.gov/pubmed/27555842.

25. Wall SK, Zhang J, Rostagno MH, Ebner PD. Phage therapy to reduce preprocessing Salmonella infections in market-weight swine. Appl Environ Microbiol. 2010;76(1):48-53. Available from: http://aem.asm.org/cgi/doi/1 0.1128/AEM.00785-09.

26. Saez AC, Zhang J, Rostagno MH, Ebner PD. Direct Feeding of Microencapsulated Bacteriophages to Reduce Salmonella Colonization in Pigs. Foodborne Pathog Dis. 2011;8(12):1269-74. https://doi.org/10.1089/fpd. 2011.0905.

27. Seo B-J, Song E-T, Lee K, Kim J-W, Jeong C-G, Moon S-H, et al. Evaluation of the broad-spectrum lytic capability of bacteriophage cocktails against various Salmonella serovars and their effects on weaned pigs infected with Salmonella Typhimurium. J Vet Med Sci. 2018;80(6):851-60. Available from: https://www.jstage.jst.go.jp/article/jvms/80/6/80_17-0501/_article.

28. Yongsheng M, Pacan JC, Wang Q, Xu Y, Huang X, Korenevsky A, et al. Microencapsulation of bacteriophage Felix $\mathrm{O} 1$ into chitosan-alginate microspheres for oral delivery. Appl Environ Microbiol. 2008;74(15):4799-805. https://doi.org/10.1128/AEM.00246-08.

29. Ma YH, Islam GS, Wu Y, Sabour PM, Chambers JR, Wang Q, et al. Temporal distribution of encapsulated bacteriophages during passage through the chick gastrointestinal tract. Poult Sci. 2016;95(12):2911-20. https://doi.org/10. 3382/ps/pew260.

30. Colom J, Cano-Sarabia M, Otero J, Aríñez-Soriano J, Cortés P, Maspoch D, et al. Microencapsulation with alginate/ $\mathrm{CaCO}_{3}$ : a strategy for improved phage therapy. Sci Rep. 2017;7(1):41441. Available from: http://www.nature. com/articles/srep41441.

31. Colom J, Cano-Sarabia M, Otero J, Cortés P, Maspoch D, Llagostera M. Liposome-Encapsulated Bacteriophages for Enhanced Oral Phage Therapy against Salmonella spp. Appl Environ Microbiol. 2015;81(14):4841-9. https:// doi.org/10.1128/AEM.00812-15.

32. Lister SA, Barrow P. Enterobacteriaceae. In: Poultry Diseases: Elsevier; 2008. p. 110-45. Available from: https://www.sciencedirect.com/science/article/pii/ B9780702028625500131.

33. Huff W, Huff G, Rath N, Balog J, Donoghue A. Prevention of Escherichia coli infection in broiler chickens with a bacteriophage aerosol spray. Poult Sci. 2002;81(10):1486-91. Available from: http://www.ncbi.nlm.nih.gov/ pubmed/12412913.

34. Huff WE, Huff GR, Rath NC, Balog JM, Xie H, Moore PA, et al. Prevention of Escherichia coli respiratory infection in broiler chickens with bacteriophage (SPR02). Poult Sci. 2002;81(4):437-41. Available from: http://www.ncbi.nlm. nih.gov/pubmed/11998827.

35. Huff W, Huff G, Rath N, Balog J, Donoghue A. Evaluation of aerosol spray and intramuscular injection of bacteriophage to treat an Escherichia coli respiratory infection. Poult Sci. 2003;82(7):1108-12. Available from: http:// www.ncbi.nlm.nih.gov/pubmed/12872966.

36. Huff WE, Huff GR, Rath NC, Balog JM, Donoghue AM. Therapeutic efficacy of bacteriophage and Baytril (enrofloxacin) individually and in combination to treat colibacillosis in broilers. Poult Sci. 2004;83(12):1944-7. https:/doi.org/ 10.1093/ps/83.12.1944.

37. Oliveira A, Sereno R, Azeredo J. In vivo efficiency evaluation of a phage cocktail in controlling severe colibacillosis in confined conditions and experimental poultry houses. Vet Microbiol. 2010;146(3-4):303-8. Available from: http://www.ncbi.nlm.nih.gov/pubmed/20605377.

38. El-Gohary FA, Huff WE, Huff GR, Rath NC, Zhou ZY, Donoghue AM. Environmental augmentation with bacteriophage prevents colibacillosis in broiler chickens1. Poult Sci. 2014;93(11):2788-92. Available from: http:// www.ncbi.nlm.nih.gov/pubmed/25214555.

39. Barrow P, Lovell M, Berchieri A. Use of lytic bacteriophage for control of experimental Escherichia coli septicemia and meningitis in chickens and calves. Clin Diagn Lab Immunol. 1998;5(3):294-8. Available from: http:// www.ncbi.n/m.nih.gov/pubmed/9605979.

40. Smith HW, Huggins MB. Successful treatment of experimental Escherichia coli infections in mice using phage: its general superiority over antibiotics. Microbiology. 1982;128(2):307-18. Available from: http://www.ncbi.nlm.nih. gov/pubmed/7042903.

41. Smith HW, Huggins MB. Effectiveness of phages in treating experimental Escherichia coli Diarrhoea in calves, piglets and lambs.
Microbiology. 1983;129(8):2659-75. Available from: http://www.ncbi.nlm. nih.gov/pubmed/6355391.

42. Smith HW, Huggins MB, Shaw KM. The control of experimental Escherichia coli Diarrhoea in calves by means of bacteriophages. Microbiology. 1987;133(5):1111-26. Available from: http://www.ncbi.nlm. nih.gov/pubmed/3309177.

43. Jamalludeen N, Johnson RP, Shewen PE, Gyles CL. Evaluation of bacteriophages for prevention and treatment of diarrhea due to experimental enterotoxigenic Escherichia coli 0149 infection of pigs. Vet Microbiol. 2009;136(1-2):135-41. Available from: https://linkinghub.elsevier. com/retrieve/pii/S0378113508004987.

44. Yan L, Hong SM, Kim IH. Effect of bacteriophage supplementation on the growth performance, nutrient digestibility, blood characteristics, and fecal microbial shedding in growing pigs. Asian-Australas J Anim Sci. 2012;25(10): 1451-6. https://doi.org/10.5713/ajas.2012.12253.

45. Kim KH, Ingale SL, Kim JS, Lee SH, Lee JH, Kwon IK, et al. Bacteriophage and probiotics both enhance the performance of growing pigs but bacteriophage are more effective. Anim Feed Sci Technol. 2014;196:88-95. Available from: https://linkinghub.elsevier.com/ retrieve/pii/S0377840114001989.

46. Lee S, Hosseindoust A, Goel A, Choi Y, Kwon IK, Chae B. Effects of dietary supplementation of bacteriophage with or without zinc oxide on the performance and gut development of weanling pigs. Ital J Anim Sci. 2016; 15(3):412-8. Available from: https://www.tandfonline.com/doi/full/10.1080/1 $828051 X .2016 .1188676$

47. Bin CS, Yoo AN, Lee WJ, Shin MK, Jung MH, Shin SW, et al. Effect of bacteriophage in enterotoxigenic Escherichia coli (ETEC) infected pigs. J Vet Med Sci. 2012;74(8):1037-9. Available from: http://www.ncbi.nlm.nih.gov/ pubmed/22446401.

48. European Food Safety Authority (EFSA). The European Union Summary Report on Trends and Sources of Zoonoses, Trends and Sources of Zoonoses, Zoonotic Agents and Food-borne Outbreaks in 2017. 2018. [Internet]. Available from: https://www.ecdc.europa.eu/sites/portal/files/ documents/zoonoese-food-borne-outbreaks-surveillance-2017-updated.pdf. Accessed 7 June 2019.

49. Black RE, Levine MM, Clements ML, Hughes TP, Blaser MJ, Black RE. Experimental Campylobacter jejuni infection in humans. J Infect Dis. 1988; 157(3):472-9. https://doi.org/10.1093/infdis/157.3.472.

50. Myszewski MA, Stern NJ. Influence of Campylobacter jejuni cecal colonization on immunoglobulin response in chickens. Avian Dis. 1990; 34(3):588-94. Available from: http://www.ncbi.nlm.nih.gov/ pubmed/2241685.

51. Rosenquist H, Nielsen NL, Sommer HM, Nørrung B, Christensen BB. Quantitative risk assessment of human campylobacteriosis associated with thermophilic Campylobacter species in chickens. Int J Food Microbiol. 2003; 83(1):87-103. https://doi.org/10.1016/s0168-1605(02)00317-3.

52. Food Standards Agency (FSA). Antimicrobial resistance in Campylobacter jejuni and Campylobacter coli from retail chilled chicken in the UK (Year 3: 2016-17) [Internet]. 2018. Available from: https://www.food.gov.uk/sites/ default/files/media/document/antimicrobial-resistance-in-campylobacterjejuni-and-campylobacter-coli-from-retail-chilled-chicken-in-the-uk-year-3-2 016-17.pdf. Accessed 7 June 2019.

53. Wagenaar JA, Van Bergen MAP, Mueller MA, Wassenaar TM, Carlton RM. Phage therapy reduces Campylobacter jejuni colonization in broilers. Vet Microbiol. 2005;109(3-4):275-83. Available from: http://www.ncbi.nlm.nih. gov/pubmed/16024187.

54. Loc-Carrillo C, Atterbury RJ, El-Shibiny A, Connerton PL, Dillon E, Scott A, et al. Bacteriophage therapy to reduce Campylobacter jejuni colonization of broiler chickens. Appl Environ Microbiol. 2005;71(11):6554-63. Available from: http://www.ncbi.nlm.nih.gov/pubmed/16269681.

55. Atterbury RJ, Dillon E, Swift C, Connerton PL, Frost JA, Dodd CER, et al. Correlation of Campylobacter bacteriophage with reduced presence of hosts in broiler chicken ceca. Appl Environ Microbiol. 2005;71(8):4885-7. Available from: http://www.ncbi.nlm.nih.gov/pubmed/16085889.

56. Jäckel C, Hammerl J, Hertwig S. Campylobacter phage isolation and characterization: what we have learned so far. Methods Protoc. 2019;2(1):18. Available from: http://www.mdpi.com/2409-9279/2/1/18.

57. Coward C, Grant AJ, Swift C, Philp J, Towler R, Heydarian M, et al. Phasevariable surface structures are required for infection of Campylobacter jejuni by bacteriophages. Appl Environ Microbiol. 2006;72(7):4638-47. https://doi. org/10.1128/AEM.00184-06. 
58. Sørensen MCH, van Alphen LB, Harboe A, Li J, Christensen BB, Szymanski CM, et al. Bacteriophage F336 recognizes the capsular phosphoramidate modification of Campylobacter jejuni NCTC11168. J Bacteriol. 2011;193(23):6742-9. https:/doi. org/10.1128/JB.05276-11.

59. Sørensen MCH, van Alphen LB, Fodor C, Crowley SM, Christensen BB, Szymanski CM, et al. Phase Variable Expression of Capsular Polysaccharide Modifications Allows Campylobacter jejuni to Avoid Bacteriophage Infection in Chickens. Front Cell Infect Microbiol. 2012;2:11. https://doi.org/10.3389/ fcimb.2012.00011.

60. El-Shibiny A, Scott A, Timms A, Metawea Y, Connerton P, Connerton I. Application of a group II Campylobacter bacteriophage to reduce strains of Campylobacter jejuni and Campylobacter coli colonizing broiler chickens. J Food Prot. 2009;72(4):733-40. Available from: http://www.ncbi.nlm.nih.gov/ pubmed/19435220.

61. Hammerl JA, Jäckel C, Alter T, Janzcyk P, Stingl K, Knüver MT, et al. Reduction of Campylobacter jejuni in Broiler Chicken by Successive Application of Group II and Group III Phages. PLoS One. 2014;9(12):e114785. Available from: https://dx.plos.org/10.1371/journal.pone.0114785.

62. Carvalho CM, Gannon BW, Halfhide DE, Santos SB, Hayes CM, Roe JM, et al. The in vivo efficacy of two administration routes of a phage cocktail to reduce numbers of Campylobacter coli and Campylobacter jejuni in chickens. BMC Microbiol. 2010;10(1):232. Available from: http://bmcmicrobiol. biomedcentral.com/articles/10.1186/1471-2180-10-232.

63. Richards PJ, Connerton PL, Connerton IF. Phage biocontrol of Campylobacter jejuni in chickens does not produce collateral effects on the gut microbiota. Front Microbiol. 2019:10:476. Available from: http://www. ncbi.nlm.nih.gov/pubmed/30930877.

64. Prescott JF, Parreira VR, Mehdizadeh Gohari I, Lepp D, Gong J. The pathogenesis of necrotic enteritis in chickens: what we know and what we need to know: a review, Avian Pathol. 2016;45(3):288-94. Available from: http://www.ncbi.nlm.nih.gov/pubmed/26813023.

65. Van Immerseel F, De Buck J, Pasmans F, Huyghebaert G, Haesebrouck F, Ducatelle R. Clostridium perfringens in poultry: an emerging threat for animal and public health. Avian Pathol. 2004;33(6):537-49. Available from: http:// www.tandfonline.com/doi/abs/10.1080/03079450400013162.

66. Miller RW, Skinner J, Sulakvelidze A, Mathis GF, Hofacre CL. Bacteriophage therapy for control of necrotic enteritis of broiler chickens experimentally infected with Clostridium perfringens. Avian Dis. 2010;54(1):33-40. Available from: http://www.ncbi.nlm.nih.gov/pubmed/20408396.

67. Fischetti VA. Bacteriophage endolysins: A novel anti-infective to control Gram-positive pathogens. Int J Med Microbiol. 2010;300:357-62. https://doi. org/10.1016/j.jimm.2010.04.002.

68. Zimmer M, Vukov N, Scherer S, Loessner MJ. The murein hydrolase of the bacteriophage phi3626 dual lysis system is active against all tested Clostridium perfringens strains. Appl Environ Microbiol. 2002;68(11):5311-7. Available from: http://www.ncbi.nlm.nih.gov/pubmed/12406719.

69. Zimmer M, Scherer S, Loessner MJ. Genomic analysis of Clostridium perfringens bacteriophage phi3626, which integrates into guaA and possibly affects sporulation. J Bacteriol. 2002;184(16):4359-68. Available from: http:// www.ncbinlm.nih.gov/pubmed/12142405

70. Gervasi T, Horn N, Wegmann U, Dugo G, Narbad A, Mayer MJ. Expression and delivery of an endolysin to combat Clostridium perfringens. Appl Microbiol Biotechnol. 2014;98(6):2495-505. Available from: http://www.ncbi. nlm.nih.gov/pubmed/23942878.

\section{Publisher's Note}

Springer Nature remains neutral with regard to jurisdictional claims in published maps and institutional affiliations.

Ready to submit your research? Choose BMC and benefit from:

- fast, convenient online submission

- thorough peer review by experienced researchers in your field

- rapid publication on acceptance

- support for research data, including large and complex data types

- gold Open Access which fosters wider collaboration and increased citations

- maximum visibility for your research: over $100 \mathrm{M}$ website views per year

At $\mathrm{BMC}$, research is always in progress.

Learn more biomedcentral.com/submissions 